\title{
The Swedish childhood diabetes study - social and perinatal determinants for diabetes in childhood
}

\author{
L. Blom ${ }^{1}$, G. Dahlquist ${ }^{1}$, L. Nyström ${ }^{2}$, A. Sandström ${ }^{2}$ and S. Wall ${ }^{2}$ \\ ${ }^{1}$ Department of Paediatrics, Karolinska Institute, Sachs' Children's Hospital, Stockholm and \\ 2 Department of Epidemiology and Health Care Research, University of Umeå, Sweden
}

\begin{abstract}
Summary. Using the Swedish childhood diabetes register, a nationwide, case-referent study was performed from September 1, 1985 to August 31, 1986. Based on the information from a mailed questionnaire sent to all incident diabetic children and for each diabetic child - two referent children matched according to age, sex, and county, we have analysed perinatal events and aspects of the social environment as possible risk factors for Type 1 (insulin-dependent) diabetes in childhood. A significantly larger proportion of the mothers of the diabetic children were older than 40 years compared to those of the referent children ( $33 \%$ and $24 \%, p=0.01$ respectively). A smaller percentage of mothers of the diabetic children had a high educational level compared to mothers of referent children ( $10 \%$ and $15 \%, p=0.03$ respectively) and $39 \%$ of the fathers of the diabetic children were manual workers compared to $31 \%$ of the fathers of referent children $(p=0.03)$. Perinatal events did not differ between diabetic and referent children. In chil-
\end{abstract}

dren $0-6$ years, the duration of breast-feeding was significantly shorter in diabetic children than among referent children (median duration for diabetic children 5 months compared to 6 months for referent children $p=0.03$ ). When considering the presence of Type 1 diabetes among relatives, maternal age over 40 years, low educational level of the mother, and the father being a manual worker as risk factors, the presence of 1 to 4 of any of these risk factors increased the relative risk for Type 1 diabetes cumulatively from 1.2-7.5. In conclusion, breast-feeding habits and probably other factors dependent on maternal age and the social status of the family may further increase the risk for Type 1 diabetes in genetically susceptible individuals.

Key words: Type 1 (insulin-dependent) diabetes, childhood, social environment, perinatal factors, breast-feeding, epidemiology.
The current hypothesis on the aetiology of Type 1 (insulin-dependent) diabetes mellitus is that the disease develops in genetically susceptible individuals as an autoimmune disease, triggered by environmental factors [1]. There is indisputable evidence for a clear association between markers of the HLA-region of chromosome 6 and early B-cell destruction in Type 1 diabetes [2]. On the other hand, the importance of environmental factors is illustrated by studies showing that the concordance of Type 1 diabetes in homozygotic twins is only $35-50 \%$ [3]. Environmental factors are also indicated by the rapid increasing incidence of Type 1 diabetes reported from several countries [4-11], as well as by the geographical variation in incidence prevailing between different Scandinavian countries [12] and also between different regions within Sweden [11], despite the genetic homogeneity of the population.

B-cell destruction may begin many years before the clinical onset of the disease [13]. Viral infections have been suggested to trigger the mechanisms leading to Bcell destruction [14-16], and there is a many-fold risk for Type 1 diabetes in children affected by rubella infection in-utero [17]. Thus, when looking for possible environmental factors triggering the development of disease in children, it is wise to consider the whole life span of the child including intra-uterine life. Different forms of stress (social, psychological and physical) may influence the time of onset of Type 1 diabetes considering the insulin-antagonistic effect of cathecholamines shown in normal man [18].

Food may be of aetiological importance for Type 1 diabetes. Previous studies have indicated that the duration of breast-feeding [19], differences in protein composition [20] or the presence of toxic agents in food such as nitroseamines [21] may influence the risk of developing Type 1 diabetes. The rising incidence of Type 1 diabetes with age in children with a peak incidence in early puberty concomitant with the maximum growth velocity period [11] suggests a connection between the mechanisms of growth and the risk of developing Type 1 diabetes in children. Thus, Type 1 diabetes is probably caused by many co-operating, qualitatively different, aetiological factors, ultimately resulting in clinical disease; a conceptual model is presented in Figure 1.

The first major step to test hypotheses on environmental factors of possible importance for the aetiology of a disease is to apply proper epidemiological methods. The choice of study design is determined by factors such as incidence rate of the disease studied, time between relevant exposure and clinical onset of disease 


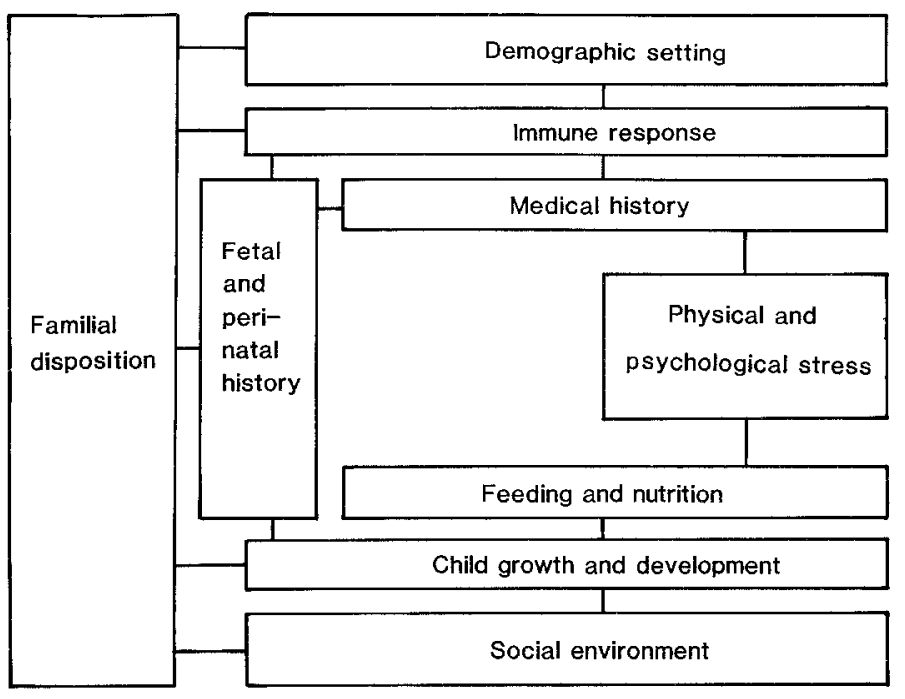

Table 1. Subjects

\begin{tabular}{|c|c|c|c|c|c|c|c|c|}
\hline \multirow{2}{*}{$\begin{array}{l}\text { Age } \\
\text { (years) }\end{array}$} & \multicolumn{4}{|c|}{ Diabetic children } & \multicolumn{4}{|c|}{ Referent children } \\
\hline & $\begin{array}{l}\text { Boys } \\
(n)\end{array}$ & $(\%)$ & $\begin{array}{l}\text { Girls } \\
\text { (n) }\end{array}$ & $(\%)$ & $\begin{array}{l}\text { Boys } \\
(n)\end{array}$ & $(\%)$ & $\begin{array}{l}\text { Girls } \\
(n)\end{array}$ & $(\%)$ \\
\hline $0-4$ & 40 & 22.3 & 32 & 20.0 & 71 & 25.1 & 47 & 19.2 \\
\hline 5- 9 & 66 & 36.9 & 49 & 30.6 & 97 & 34.3 & 71 & 29.0 \\
\hline $10-14$ & 73 & 40.8 & 79 & 49.4 & 115 & 40.6 & 127 & 51.8 \\
\hline $0-14$ & 179 & 100.0 & 160 & 100.0 & 283 & 100.0 & 245 & 100.0 \\
\hline
\end{tabular}

$n=$ number of children studied

Table 2. Reasons for non-response

\begin{tabular}{lrrrrr}
\hline & \multicolumn{2}{c}{ Diabetic children } & & \multicolumn{2}{c}{ Referent children } \\
\cline { 6 - 6 } & $(n)$ & $(\%)$ & & $(n)$ & $(\%)$ \\
\hline Questionnaire answered & & & & & \\
Reason for not answering: & 339 & 86 & & 528 & 67 \\
a) "Active refuser"a & 13 & 3 & & 76 & 10 \\
b) "Passive refuser"b & 19 & 5 & & 67 & 8 \\
c) No telephone & 15 & 4 & & 83 & 11 \\
d) Difficulties with the & & & & & \\
Swedish language & 0 & & & 6 & 1 \\
e) Other reasons & 7 & 2 & & 26 & 3 \\
\hline Total & 393 & 100 & & 786 & 100 \\
\hline
\end{tabular}

a "Active refuser" = parent who actively refused to participate in the study

b "Passive refuser" = parent who was positive to participate but did not return the questionnaire in spite of repeated telephone remindings. $n=$ number of children studied

and also by the prevalence of the suspected exposure. To study a disease like Type 1 diabetes in childhood with a relatively low incidence rate in a population and, at least in some cases, a long incubation period, the case-referent study design would be appropriate [22].

Since July 1, 1977, all incident cases of Type 1 diabetes in Sweden 0-14 years have been prospectively registered [11]. Based on this register, we have performed an incident case-referent study comprising all new cases with Type 1 diabetes during one year and age-, sex, and county-matched control group. To cover

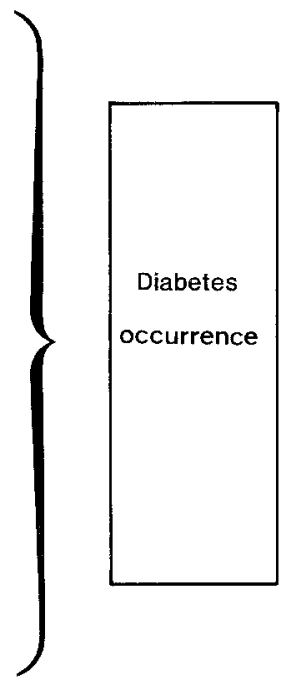

Fig. 1. Conceptual model for the interrelations of different factors of possible importance in the occurrence of Type 1 (insulin-dependent) diabetes in childhood the variables of hypothetical importance for the aetiology of Type 1 diabetes as indicated in Figure 1, data from a questionnaire and from serum analyses were collected from diabetic and referent children.

In the present report, we have analysed the possible influence of social environment, fetal and perinatal events and infant feeding on the risk to develop Type 1 diabetes in childhood.

\section{Subjects and methods}

The study was approved by the Ethics Committee at the Karolinska Institute as well as by the Swedish Data Inspection Board.

In the Swedish health care system, all children 0-14 years with suspected diabetes are referred to the paediatric departments. A standardised form is used to report basic data on new cases of Type 1 diabetes in children from all of the 44 paediatric departments to the Swedish childhood diabetes study as previously described in detail [23]. Careful check-ups are performed monthly to correct inaccurate or missing data. The case-referent study covered all incident diabetic children from September 1, 1985 to August 31, 1986, and for each diabetic child - two children matched according to age, sex, and county were studied. The referent children were traced using the official Swedish population register (SPAR-DAFA). Approximately four weeks after diagnosis of diabetes of a child, this child and its two referent children received a mailed questionnaire. The questionnaire was introduced by a letter which presented the study in general terms and its aim to investigate possible connections between diseases in children and environmental factors. To avoid primary recall bias, the specific focus on diabetes was not mentioned.

If the questionnaires were not returned within a few weeks, the families were reminded by post cards and if necessary also by telephone. Questionnaires incompletely or inaccurately filled in were corrected by telephone interviews. Eighty-six percent (339/393) of the diabetic children returned the questionnaires and $67 \%(527 / 786)$ of the referent children. The number of diabetic and referent children in different age groups are given in Table 1. Reasons for non-response, expressed in telephone interviews, are given in Table 2. There was no systematic difference in diabetic or referent children who returned or did not return the questionnaire as to age, sex and county.

The part of the questionnaire analysed here covered questions concerning: (1) fetal and perinatal factors, such as infections and other complications during pregnancy, medication during pregnancy, maternal age, mode of delivery, gestational age, birth weight and length, need for care in a neonatal ward, breast feeding and infant feeding; (2) factors concerning social environment, such as parental 
age at onset of disease, number of siblings, type of daily care of preschool children, marital status of parents, number of times the child has moved house, education and occupation of parents, proportion of immigrants among parents.

\section{Statistical analysis}

When analysing data in this case-referent study, the matching was dissolved to avoid loss of valuable information during analysis. This was possible since the ratios between matched and unmatched data were close to one [24]. Chi-square test was used when comparing frequencies between cases and referents.

The relative risks were estimated by odds ratios and $95 \%$ confidence intervals calculated according to Miettinen [25]. Differences of mean group values were estimated using Mann-Whitney U-test, as data were not normally distributed. As the exposure of different possible risk factors analysed differ and the least detectable increased risk $(R)$ varies as a function of the proportion of exposed referent children, Table 3 was constructed to show the least detectable risk provided a type I error of $5 \%$ and a type II error of $10 \%$ when the number of diabetic children and referent children are the 339 and 528, respectively [26], as used in the present study. Thus, for uncommon exposures in both diabetic children and referent children, such as low birth weight, only odds ratios well above 2 will be detectable.

\section{Results}

\section{Social environment}

Family characteristics. Family types, number of siblings and proportion of adopted or foster children were similar among diabetic and referent children, as shown in Table 4 . The mean age of the fathers was 39 years in diabetic and referent children. The corresponding figures for the mothers were 37 and 36, respectively. However, a significantly larger proportion of the mothers of the diabetic children were 40 years or older compared to the mothers of the referent children as seen in Table $3\left(\mathrm{X}^{2}=6.62, p=0.01\right)$. Using mothers age $\geqq 40$ years as a risk category, the odds ratio for Type 1 diabetes in children was 1.50 (95\% confidence interval 1.11-2.03). When looking at the nationality of the family members, we found a tendency that a greater proportion of both fathers and mothers of referent children were immigrants to Sweden (Table 4), but the tendency did not reach statistical significance $\left(\mathrm{X}^{2}=2.8, p=0.09\right.$ and $\mathrm{X}^{2}=0.6, p=0.44$ for fathers and mothers, respectively), and the parental pattern of nationality did not differ between diabetic and referent children. Two thirds of the immigrant parents came from the nordic countries.

Social status. The level of education and type of occupation in parents of diabetic and referent children was analysed according to the official Swedish population register [27] and the results are given in Table 5. In both fathers and mothers, there is a tendency towards a shorter and more practical type of education in the parents of diabetic children, and when looking at mothers, we found a significantly lower proportion of education at university level among the mothers of diabetic children than among mothers of referent children $\left(\mathrm{X}^{2}=4.44\right)$, $p=0.03$ ). The proportion of fathers of diabetic children
Table 3. Smallest detectable relative risk $(\mathrm{R})$ at different levels of exposure of referents $\left(\mathrm{P}_{\mathrm{O}}\right)$ at $5 \%$ level of significance and provided the power of the study is 0.90

\begin{tabular}{llllllll}
\hline Po & 0.01 & 0.05 & 0.1 & 0.3 & 0.5 & 0.7 & 0.9 \\
$\mathrm{R}$ & 3.82 & 2.03 & 1.72 & 1.46 & 1.43 & 1.51 & 2.01 \\
\hline
\end{tabular}

Table 4. Family characteristics

\begin{tabular}{lcc}
\hline Family characteristics & $\begin{array}{l}\text { Diabetic } \\
\text { children } \\
(\%)\end{array}$ & $\begin{array}{c}\text { Referent } \\
\text { children } \\
(\%)\end{array}$ \\
\hline Parents, married or co-habitant & 87.0 & 86.6 \\
Single parent & 6.8 & 8.8 \\
Parent + new partner & 5.6 & 4.2 \\
Missing data & 0.6 & 0.4 \\
Adopted or foster child & 1.4 & 2.7 \\
Number of siblings & & \\
0 & 11.5 & 11.2 \\
1-2 & 76.1 & 77.8 \\
3-6 & 12.4 & 11.0 \\
Father's age & & \\
19-39 years & 50.4 & 52.1 \\
40-65 & 41.0 & 39.2 \\
missing data & 8.6 & 8.7 \\
Mother's age & & \\
19-39 years & 65.5 & 73.5 \\
40 65 & $32.7^{\mathrm{a}}$ & $24.4^{\mathrm{a}}$ \\
missing data & 1.8 & 2.1 \\
Proportions of immigrants & & 11.2 \\
fathers & 6.6 & 10.4 \\
mothers & 8.0 & \\
\hline
\end{tabular}

a Proportions statistically different between diabetic and referent children $(p \leqq 0.05) ;{ }^{\mathrm{b}}$ Questions about parental nationality asked for in later part of the study. Thus, results are on responses from 213/339 diabetic and 326/528 referent children

Table 5. Education and occupation of parents

\begin{tabular}{|c|c|c|c|c|}
\hline \multirow[t]{2}{*}{$\begin{array}{l}\text { Parental education } \\
\text { and occupation }\end{array}$} & \multicolumn{2}{|c|}{$\begin{array}{l}\text { Diabetic children } \\
(\%)\end{array}$} & \multicolumn{2}{|c|}{$\begin{array}{l}\text { Referent children } \\
(\%)\end{array}$} \\
\hline & Fathers & Mothers & Fathers & Mothers \\
\hline \multicolumn{5}{|l|}{ Education } \\
\hline $\begin{array}{l}\text { Elementary or } \\
\text { compulsory school }\end{array}$ & 32.7 & 32.7 & 32.5 & 32.6 \\
\hline Vocational school & 19.8 & 15.1 & 14.8 & 11.2 \\
\hline High school & 17.4 & 18.9 & 18.6 & 20.2 \\
\hline University & 12.4 & $10.0^{\mathrm{a}}$ & 17.2 & $15.2^{\mathrm{a}}$ \\
\hline Other education & 15.3 & 21.2 & 15.2 & 20.0 \\
\hline Missing data & 2.4 & 2.1 & 1.7 & 0.8 \\
\hline \multicolumn{5}{|l|}{ Occupation } \\
\hline Manual worker & $38.6^{\mathrm{a}}$ & 37.8 & $31.2^{\mathrm{a}}$ & 35.6 \\
\hline Salaried enployee & 39.5 & 39.2 & 42.4 & 41.3 \\
\hline Self-employed & 17.4 & 6.8 & 19.7 & 6.6 \\
\hline Domestic work & 0.0 & 12.1 & 0.0 & 12.5 \\
\hline Student & 0.9 & 2.9 & 2.7 & 2.5 \\
\hline Pensioner & 0.6 & 0.0 & 0.0 & 0.4 \\
\hline $\begin{array}{l}\text { Unemployed parents or } \\
\text { missing data }\end{array}$ & 3.0 & 1.2 & 4.0 & 1.1 \\
\hline
\end{tabular}

a Proportions statistically different between diabetic and referent children $(p \leqq 0.05)$ 
Table 6. Influence of familial Type 1 diabetes as a confounding factor on some studied social factors

\begin{tabular}{lllll}
\hline Risk determinants & $\begin{array}{l}\text { Type } 1 \text { diabetes in rela- } \\
\text { tives. Odds ratio and } \\
95 \% \text { confidence limits }\end{array}$ & $\begin{array}{l}\text { No Type } 1 \text { diabetes in } \\
\text { relatives. Odds ratio and } \\
95 \% \text { confidence limits }\end{array}$ \\
\hline $\begin{array}{l}\text { Mothers } \geqq 40 \text { years } \\
\begin{array}{l}\text { Low maternal } \\
\text { education }\end{array}\end{array}$ & 1.30 & $(0.66-2.55)$ & 1.52 & $(1.06-2.19)$ \\
$\begin{array}{l}\text { Father manual } \\
\text { worker }\end{array}$ & 0.91 & $(0.90-2.54)$ & 1.53 & $(0.60-3.90)$ \\
\hline
\end{tabular}

Table 7. Fetal and perinatal events

\begin{tabular}{llc}
\hline Event & $\begin{array}{l}\text { Diabetic } \\
\text { children } \\
(\%)\end{array}$ & $\begin{array}{l}\text { Referent } \\
\text { children } \\
(\%)\end{array}$ \\
\hline $\begin{array}{l}\text { Maternal infections } \\
\text { during pregnancy }\end{array}$ & 21.3 & 19.8 \\
Maternal complications & 27.5 & 27.2 \\
$\quad$ during pregnancy & & \\
Mode of delivery & & \\
$\quad$ vaginal & 91.2 & 91.9 \\
Caesarian section & 8.8 & 8.1 \\
Care in neonatal ward & 13.4 & 14.1 \\
Birth weight (g) & & \\
$\quad<2500$ & 2.1 & 3.6 \\
$\quad 2500-4500$ & 95.2 & 2.1 \\
$>4500$ & 2.7 & 12.4 \\
Gestational age at birth (weeks) & & 71.9 \\
$\quad<38$ & 13.0 & 15.7 \\
$\quad 38-42$ & 72.8 & \\
$>42$ & 14.2 & \\
\hline
\end{tabular}
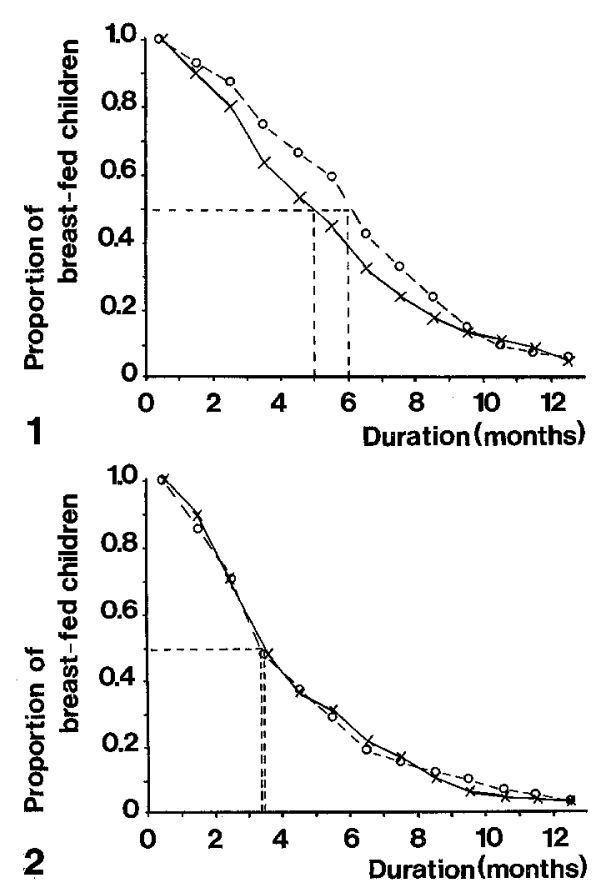

Fig. 2. Duration of breast-feeding in diabetic $(x-x)$ and referent $(0---O)$ children in the age groups $0-6$ years $(1)$ and $7-14$ years $(2)$. Dotted boxes (---) designate median values being manual workers was greater than that of fathers of referent children $\left(\mathrm{X}^{2}=4.56, p=0.03\right)$. If considering mothers having "non-university" type of education and fathers being manual workers as risk categories for diabetes in children, the odds ratios were 1.58 (95\% confidence interval 1.03-2.42) and 1.37 (95\% confidence interval 1.03-1.83), respectively.

Previous analysis from the Swedish childhood diabetes study [23] has shown that the risk to develop Type 1 diabetes in childhood is significantly increased $(p<0.05)$ when Type 1 diabetes is reported among relatives (i.e. parents, grandparents and parental siblings, cousins and siblings) with an odds ratio of 5.5 (95\% confidence interval 4.0-7.7). To control for Type 1 diabetes in relatives as a confounding factor, the subjects were sub-grouped in strata with or without Type 1 diabetes among relatives. When each risk factor is analysed separately, the odds ratios and $95 \%$ confidence limits are affected according to Table 6.

The proportion of pre-school children below 7 years of age who attended some form of organised outside home care was somewhat smaller $(43 \%)$ in diabetic than in referent children $(57 \%)\left(\mathrm{X}^{2}=4.06, p=0.03\right)$. When analysing the frequency of migration within the country, we found that the families with a diabetic child tended to be more stationary than were the referent families. Looking at the frequencies of families who have not moved house during the lifetime of their child, $60 \%$ of the families with a diabetic child belonged to that particular category compared to $52 \%$ of the referent families, a difference which is statistically significant $\left(\mathrm{X}^{2}=5.01, p=0.02\right)$.

\section{Fetal and perinatal events}

Different aspects of intra-uterine, intrapartum and neonatal factors are described in Table 7. The amount and type of infections and complications during pregnancy was similar in diabetic and referent children, and so was the proportion and type of maternal medication during pregnancy. The proportion of children delivered by Caesarean section was similar in both groups and so was the need for neonatal care in paediatric wards. No major difference were found between diabetic and referent children concerning gestational age, weight and length at birth. Mean maternal age at delivery was also equal for diabetic and referent children $(27.6 \pm 5.1$ and $27.0 \pm 4.7$, respectively). The proportion of mothers being $>35$ years at delivery, however, tended to be higher in diabetic children compared to the referent children $\left(\mathrm{X}^{2}=3.6, p=0.05\right)$. Paternal age at the child birth was equal in both groups.

\section{Breast-feeding habits}

Habits of breast-feeding (complete or partial), analysed for the whole group of children, revealed that the proportion of children who were breast-fed was similar in 
diabetic and referent children $(91 \%$ and $87 \%$ respectively). When comparing all diabetic and referent children, no difference in duration of breast-feeding was found (medan values 4 months). As the frequency and duration of breast-feeding has greatly increased in Sweden during the last decade, the children were divided into two age-groups, 0-6 and 7-14 years, respectively. As illustrated in Figure 2, referent children younger than 7 years had a significantly longer duration of breastfeeding compared to the diabetic children $(p=0.03)$. The median duration of breast-feeding in diabetic children was 5 months and the corresponding figures for referent children were 6 months. This difference was not found in children 7-14 years where the median duration of breast-feeding was only 3 complete months for both diabetic and referent children. When considering the duration of breast-feeding $<3$ months as a risk category of Type 1 diabetes in the child, the odds ratio was 1.7 and 95\% confidence limits 1.02-2.89 for children younger than 7 years. A slight tendency towards a longer duration of breast-feeding in mothers with a higher level of education was found both for diabetic and referent children. Focusing on the introduction of artificial feeding, no significant differences were found between diabetic and referent children in any age group.

\section{Effects on the relative risk of developing diabetes during childhood by a combination of different factors}

Based on our concept that different factors may in combination increase the risk of developing Type 1 diabetes in childhood (Fig.1) combinations of some of the factors studies were investigated. As mentioned above, we have previously shown that the risk of developing Type 1 diabetes in childhood is significantly increased when Type 1 diabetes is reported among relatives. Analysing the combined effect of the defined hereditary and social risk factors, we have looked at these factors as equal. When subjects with presence of 1 to 4 risk factors are compared with the group of subjects without any of these risk factors in a step-wise manner, the relative risk for Type 1 diabetes will increase from 1.2-7.5, cumulatively as shown in Table 8. As Type 1 diabetes among relatives is such a high risk factor, we have looked at the combined effect of the social risk determinant after stratification according to presence of Type 1 diabetes among relatives. Figure 3 shows that only in subjects without Type 1 diabetes among relatives, the social risk determinants will increase the odds ratio cumulatively from 1.1 to 2.9 .

\section{Discussion}

The Swedish childhood diabetes study is a populationbased epidemiological approach studying the hereditary, immunological and environmental factors influencing the aetiology of childhood Type 1 diabetes. We have chosen the case-referent design as the most
Table 8. Relative risks of developing childhood Type 1 (insulin-dependent) diabetes if exposed to 1,2,3, or 4 of any of the risk factors: Type 1 diabetes among relatives, maternal age $>40$ years, mother low education, father manual worker

\begin{tabular}{|c|c|c|c|}
\hline \multirow{2}{*}{$\begin{array}{l}\text { Number of } \\
\text { risk factors }\end{array}$} & \multirow{2}{*}{$\begin{array}{l}\text { Number of } \\
\text { diabetic } \\
\text { children }\end{array}$} & \multirow{2}{*}{$\begin{array}{l}\text { Number of } \\
\text { referent } \\
\text { children }\end{array}$} & \multirow{2}{*}{$\begin{array}{l}\text { Odds ratio ( } 95 \% \\
\text { confidence limits) }\end{array}$} \\
\hline & & & \\
\hline 0 & 13 & 46 & 1.0 \\
\hline 1 & 70 & 200 & $\begin{array}{l}1.2 \\
(0.6-2.4)\end{array}$ \\
\hline 2 & 141 & 198 & $\begin{array}{l}2.5 \\
(1.3-4.8)\end{array}$ \\
\hline 3 & 77 & 42 & $\begin{array}{l}6.4 \\
(3.3-12.9)\end{array}$ \\
\hline 4 & 17 & 8 & $\begin{array}{l}7.5 \\
(2.8-20.2)\end{array}$ \\
\hline
\end{tabular}

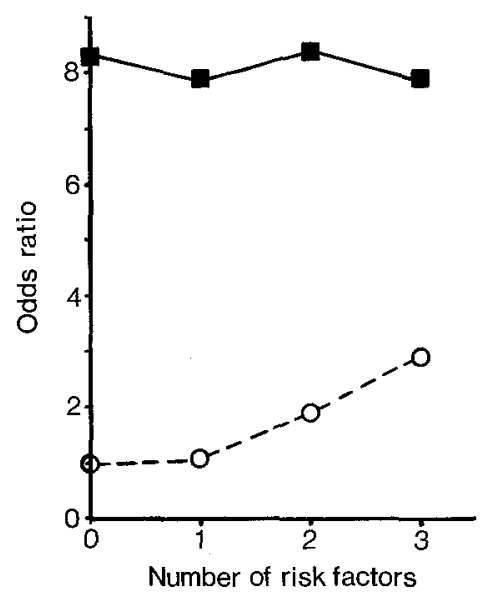

Fig. 3. Cumulative increase of relative risk of developing Type 1 diabetes if exposed to 1,2 , or 3 of any of the risk determinants: maternal age $>40$ years, mother low education, father manual worker, in subjects with familial disposition for Type 1 diabetes ( - - $)$ or without such disposition $(0---O)$. The starting point for subjects with Type 1 diabetes among relatives in set to 8.3 , i. e. the relative risk to develop Type 1 diabetes compared to the situation without any of the specified social risk determinants

cost-effective design since the disease in a population perspective is rare. A cohort approach would have taken decades and been very costly. The analysis is performed in steps according to a conceptual model (Fig.1) to decrease the problem of mass significance; thus, the present analysis concentrated on perinatal events and social factors.

The most striking finding in the present analysis was that of high maternal age being associated with Type 1 diabetes in children. This finding from our case/referent design seems to confirm the observation in family studies of a correlation between the incidence of diabetes in children and high maternal age [28], as well as the finding of an increased prevalence of Type 1 diabetes among children of mothers older than 35 years [29] and an increased risk for siblings of Type 1 diabetic cases with increased maternal age [30]. It has been speculated that the increased risk of developing diabetes 
in children of older mothers has to do with the intrauterine environment [28]. The post-natal environment may, however, in different aspects also be affected by maternal age.

In our study, we also tried to examine different aspects of intra-uterine disturbances mirrored as complications during pregnancy or at birth, as well as gestational age and birth weight, perinatal complications and need for neonatal care. No significant differences between diabetic and referent children were found in the different variables studied. As the exposure rate in the referents of some of the risk factors are comparably low, the size of the study would only detect increased risks of quite considerable magnitude (Table 3 ). When looking at breast-feeding habits in all subjects studied, we found no significant differences in the frequency or duration of breast-feeding between diabetic and referent children. As during the last decade, a rapid increase in both the practise and duration of breast-feeding has occurred in Sweden [31]; we divided the children into two age-groups and could then confirm an increase in breast-feeding duration as the medium duration had increased from 3 to 6 months in the referent children when comparing children 0-6 years to those 7-14 years. For diabetic children, however, the duration of breastfeeding in the youngest children was significantly lower in the young age group, a finding which is in agreement with the report by Borch-Johnsen [19] in Denmark. These authors have speculated that breast-feeding has a protective effect against diabetes because of the early supply of immunological active T-lymphocytes as well as immunoglobulins. It could also be argued that an early introduction of artificial feeding could be toxic for the young B cell. In our study, we found no support for this, as no significant difference as to the age at introduction of artificial food was found between diabetic and referent children. Although the frequency and duration of breast-feeding has steeply increased since 1972 in Sweden [31], we still find an increasing incidence of Type 1 diabetes when comparing incidence rates 1980-1983 and 1983-1986 [11]. Thus, even if our study seems to confirm an increased risk for Type 1 diabetes in children being breast-fed for a shorter time, the impact of this risk factor on the total risk for Type 1 diabetes in the population might be comparably small.

Data in our study on family characteristics, such as number of family members, number of single parent families, as well as number of mothers working, and the type and size of housing was in good agreement with the Swedish Population and Housing Census studies [27]. The finding of a significant difference in the level of education of the mothers is of interest; as many sociologists have pointed out, the influence of the mothers on the health behaviour of the family, and the children, and the level of education of the mother has been reported to correlate well with the degree of preventive health behaviour [32]. In accordance with a previous Swedish study [33], we found a tendency of longer duration of breast feeding in mothers with a higher level of education of both diabetic and referent children. As food habits and nutriment intake might affect the risk to develop Type 1 diabetes in childhood and as the maternal educational level might influence food habits [34], our notification is of interest. No difference concerning the educational level of fathers was noted among diabetic and referent children in our material, but a greater proportion of fathers of the diabetic children were manual workers. Also, the somewhat less frequent use of organized day-care for the pre-school children may indicate a tendency to a lower social status of the families with diabetic children, since at present in Sweden a larger proportion of children with parents with white collar jobs are attended to in day-care center than are children of parents with blue collar jobs [35]. Our findings are in agreement with the study in Copenhagen county where a lower incidence of Type 1 diabetes was found in the more affluent northern part of the city" county [36]. On the other hand, in Montreal, a higher incidence of juvenile-onset diabetes was found in census tracts with higher average household incomes [37].

When considering the presence of Type 1 diabetes in relatives as a confounding factor, we have shown that this powerful risk determinant affects the significance of the other factors. This could be interpreted in two ways - either a proportionally higher number of Type 1 diabetes was present among families with low social status by chance, or perhaps the prevalence of Type 1 diabetes among relatives in these groups may partly depend on low social status, which is also inherited. On the other hand, when only participants without heredity for Type 1 diabetes are included in the analysis, the relative risks of the social risk determinants increased cumulatively, which indicates their relative importance when assessing the total impact of different types of risk determinants.

However, it should be kept in mind that in this study, as in many other case-referent studies, the number of non-responders was higher among the referent children. From sociological studies, it is well known that there is a tendency to a lower response rate among both the highest and lowest social classes [38]. In our study, we could show that there was no difference as to age, sex and place of living between responders and non-responders, but a possible difference in social status between these groups, which could not be checked for ethical reasons.

In conclusion, high maternal age, short duration of breast-feeding and possibly also educational level of the mother and the occupation of the father seem to be related to the risk of developing Type 1 diabetes. Since the strength of association is moderate, the studied factors may be only indirectly connected with those factors that are directly involved in the aetio-pathogenesis of Type 1 diabetes. The causative factors behind these relationships cannot be defined from this study. Further analysis on nutrition and meal habits, physical and psychological 
stress factors and medical history which are going on at present may add to the complicated picture on the interrelations between aetiological factors of importance in the development of Type 1 diabetes in childhood.

Acknowledgements. The Swedish childhood diabetes study is supported by grants from the Swedish Medical Research Council, project number B87-27X-07 531-02B, The Karolinska Institute, Nordisk Insulin Foundation, the Novo Company, the Swedish Diabetes Association, the Swedish Medical Society, Svenska Diabetesstiftelsen, Stiftelsen Samariten and Förenade Liv Mutual Life Insurance Company.

\section{References}

1. Nerup J, Lernmark $\AA$ (1981) Autoimmunity in insulin-dependent diabetes mellitus. Am J Med 70: 135-141

2. Wilkin T, Armitage M (1986) Markers for insulin-dependent diabetes: towards early detection. Br Med J 293: 1323-1326

3. Tattersall RB, Pyke DA (1972) Diabetes in identical twins. Lancet II: $1120-1125$

4. Reunanen A, Åkerblom HK, Käär ML (1982) Prevalence and tenyear (1970-1979) incidence of insulin-dependent diabetes mellitus in children and adolescents in Finland. Acta Paediatr Scand 71: 893-899

5. Joner G, Søvik O (1981) Incidence, age at onset and seasonal variation of diabetes mellitus in Norwegian children 1973-1977. Acta Paediatr Scand 70:329-335

6. Patterson CC, Thorogood M, Smith PG, Heasman MA, Clarke JA, Mann JI (1983) Epidemiology of Type 1 (insulin-dependent) diabetes in Scotland 1968-1976. Evidence of an increasing incidence. Diabetologia 24: 238-243

7. Hägglöf B, Holmgren G, Wall S (1982) Incidence of insulindependent diabetes mellitus among children in a North-Swedish population 1938-1977. Hum Hered 32: 408-417

8. North AF, Gorwitz K, Sultz HA (1977) A secular increase in the incidence of juvenile diabetes mellitus. J Paediatr 91 : 706-710

9. Stewart-Brown S, Haslum M, Butler N (1983) Evidence for increasing prevalence of diabetes mellitus in childhood. Br Med J 286: $1855-1857$

10. Green A, Andersen PK (1983) Epidemiological studies of diabetes mellitus in Denmark: 3. Clinical characteristics and incidence of diabetes among males aged 0-19 years. Diabetologia 25: 226-230

11. Dahlquist $G$, Blom L, Holmgren $G$, Hägglöf $B$, Larsson $Y$, Sterky G, Wall S (1985) The epidemiology of diabetes in Swedish children $0-14$ years - a six year prospective study. Diabetologia 28: $802-808$

12. Christau B, Åkerblom H, Joner G, Dahlquist G, Ludvigsson J, Nerup J (1981) Incidence of childhood insulin-dependent diabetes mellitus in Denmark, Finland, Norway and Sweden. A workshop report. Acta Endocrinol Scand 98 [Suppl 245]: 68-80

13. Gorsuch AN, Spencer KM, Lister J, McNally JM, Dean BM, Bottazzo GF, Cudworth AG (1981) Evidence for a long prediabetic period in Type 1 (insulin-dependent) diabetes mellitus. Lancet II: 1363-1365

14. Menser MA, Forrest JM, Bransby RD (1978) Rubella infection and diabetes mellitus. Lancet I: 57-60

15. King ML, Shaikh A, Bidwell D, Voller A, Banatvala JE (1983) Coxsackie-B-virus specific IgM-responses in children with insulin-dependent (juvenile-onset; Type 1) diabetes mellitus. Lancet I: 1397-1399

16. Gamble DR (1980) Relation of antecedent illness to devlopment of diabetes in children. Br Med J 281: 99-101.

17. Ginsberg-Fellner F, Witt ME, Yagihashi S, Dobersen MJ, Taub F, Fedun B, McEvoy RC, Roman SH, Davies RG, Cooper LZ (1984) Congenital rubella syndrome as a model for Type 1 (insulin-dependent) diabetes mellitus: increased prevalence of islet cell surface antibodies. Diabetologia 27 [Suppl.]: 87-89

18. Lager I, Attvall S, Eriksson MB, v Schenk H, Smith U (1986) Studies on the inulin-antagonistic effect of catecholamines in nor- mal man. Evidence for the importance of beta- 2 receptors. Diabetologia 29: 409-416

19. Borch-Johnsen K, Joner G, Mandrup-Poulsen T, Christy M, Zachau-Christiansen B, Kastrup K, Nerup J (1984) Relation between breast-feeding and incidence rates of insulin-dependent diabetes mellitus. A hypothesis. Lancet II: 1083-1086

20. Elliot RB, Martin JM (1984) Dietary protein: a trigger of insulindependent diabetes in the BB rat? Diabetologia 26:297-299

21. Helgason T, Ewen SW, Ross IS, Stowers JM (1982) Diabetes produced in mice by smoked/cured mutton. Lancet II: 1017-1022

22. Ahlbom A, Norell S (1984) Introduction to modern epidemiology. Epidemiology Resources, pp 51-52

23. Dahlquist G, Blom L, Tuvemo T, Nyström L, Sandström A, Wall S (1989) The Swedish childhood diabetes study - results from a nine year case register and a one year case-referent study indicating that Type 1 (insulin-dependent) diabetes mellitus is associated with both Type 2 (non-insulin-dependent) diabetes mellitus and autoimmune disorder. Diabetologia 32: 2-6

24. Miettinen O (1972) Components of the Crude risk ratio. Am J Epidemiol 96: 168-172

25. Miettinen O (1976) Estimability and estimation in case-referent studies. Am J Epidemiol 103: 226-235

26. Schlesselman JJ (1982) Case-control studies. Oxford University Press, New York

27. The Swedish Population and Housing Census (1980) The National Central Bureau of Statistics. Liber

28. Flood TM, Brink SJ, Gleason RE (1982) Increased incidence of Type I diabetes in children of older mothers. Diabetes Care 5 (6): 571-573

29. Wagener DK, LaPorte RE, Orchard TJ, Cavender D, Kuller LH, Drash AL (1983) The Pittsburgh diabetes mellitus study. 3: an increased prevalence with older maternal age. Diabetologia 25: $82-85$

30. Cavender DE, Wagener DK, Orchard TJ, LaPorte RE, Becker DJ, Kuller LH (1984) Multivariate analyses of the risk of insulindependent diabetes mellitus for siblings of insulin-dependent diabetic patients. Am J Epidemiol 120: 315-327

31. Hofvander Y, Sjölin S (1979) Breast-feeding trends and recent information activities in Sweden. Acta Paediatr Scand [Suppl] 275: 122-125

32. Steele JL, McBroom WH (1972) Conceptual and empirical dimensions of health behaviour. J Health Soc Behav 13:382-392

33. Sjölin S, Hofvander Y, Hillervik C (1977) Factors related to termination of breast-feeding. A retrospective study in Sweden. Acta Paediatr Scand 66: 505-511.

34. Hagman U, Bruce $\AA$, Persson L-Å, Samuelson G, Sjölin S (1986) Food habits and nutrient intake in childhood in relation to health and socio-economic conditions. A Swedish multicenter study 1980-81. Acta Paediatr Scand [Suppl] 328: 1-56

35. The Swedish Central Labour Organization (LO): report no 5, $1982 / 83$, LO

36. Christau B, Kromann H, Andersen OO, Christy M, Buschard K, Arnung K, Kristensen IH, Peitersen B, Steinrud S, Nerup J (1977) Incidence, seasonal and geographical patterns of juvenile-onset insulin-dependent diabetes mellitus in Denmark. Diabetologia 13: $281-284$

37. Colle E, Siemiatychi J, West R, Belmonte MM, Crepeau MP, Poirier R, Wilkins J (1981) Incidence of juvenile onset diabetes in Montreal - demonstration of ethnic differences and socio-economic class differences. J Chron Dis 34: 611-616

38. Tibblin G (1965) A population study of 50-year-old men. An analysis of the non-participation group. Acta med Scand 178: 453-459

Received: 20 July 1988

and in revised form: 18 October 1988

Dr. L. Blom

Department of Paediatrics

Sachs' Children's Hospital

S-11669 Stockholm

Sweden 